\title{
NAVIGATING SWOT-FANP WITH GSM METHOD TO PRIORITIZE THE STRATEGIC LOCATION
}

\author{
Yun-Huei LEE \\ Tamkang University, New Taipei City, Taiwan \\ Received 07 May 2012; accepted 02 December 2012
}

\begin{abstract}
This paper proposes a SWOT-FANP (strengths, weaknesses, opportunities, and threats fuzzy analytic network process) analysis, together with the grand strategy matrix method (GSM) to deal with the multiple-criteria decision-making problem of location selection for a second tier city in China. This hybrid method can not only combine both qualitative and quantitative information and utilize fuzzy logic to eliminate vagueness, subjectivity, and imprecision, it can also clearly represents the competitive position of second-tier cities on a the quadrant coordinate to help an enterprise choose a strategy for development. To this end, I empirically chose a multinational pharmaceutical enterprise (MNE) as an illustrative example. The results reveal that Suzhou and Chongqing cities are in the best positions in the competition as a result of having external opportunities for development and internal competing strength. Moreover, the MNE could adopt a niche-focus strategy for the market by focusing on specific ailments to which people in Chinese communities are vulnerable to strengthen their competitive strengths. This study demonstrates and validates that such an enhanced methodology is viable and highly capable of providing enriched insights regarding strategic decision-making management in complex real-world situations.
\end{abstract}

Keywords: SWOT analysis, location selection, fuzzy analytic network process (FANP), Grand Strategy Matrix (GSM).

JEL Classification: C63, F23, M00.

\section{Introduction}

The main research stream regarding foreign direct investment (FDI) to China in international business over the past 30 years has been identified as the location determinants of FDI to China (Dunning, Lundan 2008), including market size and economic growth, labor factors, and government policies on foreign investment. Most related studies have examined China at

Corresponding E-mail:

yh@mail.tku.edu.tw 
the regional or provincial level or focused on so-called first-tier cities (e.g. Beijing, Shanghai, Shenzhen, and Guangzhou). However, for multinational enterprises (MNEs) either willing to invest in or currently investing in China, selecting a second-tier city through which to enter the country is a good way to protect oneself from any dramatic competition. Thus, in the case of China, there is an increasing need for research on second and third-tier cities to identify their geographical advantages and attractiveness, as well as their disadvantages, for MNEs. Such research would shift the focus from such historic "hot-spots" for inward FDI, such as Shanghai, Shenzhen, and Guangzhou, to cities on the periphery, thereby providing new set of data (Fetscherin et al. 2010). To the best of our knowledge, no study has, as of yet, explored the location of foreign investment for second-tier cities. Therefore, to fill this gap in the literature, the present study presents an attempt at selecting the best second-tier city location for such investments.

SWOT (which stands for "strengths, weaknesses, opportunities, and threats") is a popular tool used for strategic-level decision-making. It is the most widely used tool for major decision-making processes among executives working in Finland's 500 biggest companies (Stenfors, Tanner 2007). Its main application is to identify and analyze internal and external environments in support of strategic decision-making. When used properly, SWOT can provide a good basis for strategy formulation (Kajanus et al. 2004). However, SWOT analysis is not without limitations. SWOT's main weakness is an overall dependence on a qualitative analysis that merely ranks the importance of individual factors without quantitatively measuring them. Thus, SWOT analysis cannot comprehensively appraise strategic decision-making processes (Hill, Westbrook 1997), and its results often present a listing or an incomplete qualitative examination of internal and external factors (Kajanus et al. 2004). Some researchers have proposed a SWOT analysis featuring analytic network process (ANP) (Foroughi et al. 2012; Mohammad et al. 2011; Sevkli et al. 2012) which not only combine both qualitative and quantitative information, but can also deal with complex problems involving interactions among various factors. However, decision makers are usually unable to precisely identify their preference owing to uncertain judgments that involve internal inconsistency and that are often expressed in linguistic terms. This makes fuzzy logic a more natural approach to this kind of problem. Recently, the use of fuzziness in research articles has been increasing. However, there are far fewer studies on the fuzzy ANP (FANP) than there are studies on fuzzy analytic hierarchy process (FAHP). Compared with FAHP, FANP technique uses both interdependence of criteria and inner dependence of criteria with pairwise comparison matrix. Sipahi and Timor (2010) conducted a detailed literature review of the AHP and ANP methodologies, and the results show that between 2005 and 2009, SWOT with FANP was not present in the integrated methodologies involving such additional techniques as simulation, TOPSIS, GIS, and DEA used with AHP, FAHP, ANP, and FANP. Moreover, there is no hybrid method to further suggest suitable strategy development according to SWOT-FANP. Just as in the grand strategy matrix (GSM), the enterprises are parked in the four quadrants of thecoordinate according to their categories. A reversal occurs where the ordinate standsfor the external environment (opportunities and threats) while the abscissa stands for the internal environment (strengths and weaknesses) (Chang, Huang 2006). Therefore, this paper has chosen pharmaceutical MNEs currently investing in and seeking the next location for their 
market expansion in China as an illustration of the present study's proposed SWOT-FANP analysis featuring GSM. By identifying important factors such as strengths, weaknesses, opportunities, and threats, and by revealing a competitive situation on a quadrant coordinate from the findings, enterprises can not only realize their position inthe competition but also have a reference for developing strategies.

The remainder of this paper is structured as follows. The second section presents a comprehensive review of the literature, including GSM, China's determinants of FDI location choice, the FANP approach, and a summary. The third chapter describes the research methodology including model structure and concept application. The empirical analysis and findings are contained and discussed in Section 4. Section 5 concludes the paper with a discussion of managerial implications.

\section{Literature review}

\subsection{Grand strategy matrix (GSM)}

It procedure provides a reference for developing strategies in accordance with a strategic development model, such as the grand strategy matrix (GSM) (Chou et al. 2001). In the GSM model, location is parked in one of the four quadrants of the coordinate grid according to its environmental position. The meaning of the four quadrants is as follows: the first quadrant stands for the enterprises' strengths and market opportunities in the location. Locations in the second quadrant are those with market development opportunities but which tend towards a weak environmental position. The most urgent issue for such firms is to address their weaknesses to intensify competitive strength. Locations in the third quadrant have low competitive strength and face threats from other competitors. Locations in the fourth quadrant process competitive strength but face greater threats than opportunities (Chen et al. 1992; Lee, Lin 2008).

\subsection{The determinants of FDI-location choice}

An extensive body of research has examined the determinants of FDI-location choice in China. The determinants can be explained on the basis of some location theories, especially "internalisation" theory (Coase 1937; Penrose 1959), the eclectic paradigm (Dunning 2001), and macro-economic approaches (Kojima 1982; Kojima, Ozawa 1984). We can understand the location choice of foreign investment in China from these theories. Some researchers stressed that wage costs are the most important factor in location selection (Cheng, Kwan 2000; Coughlin, Segev 2000). Other positive determinants of city attractiveness for future FDI are market size (Na, Lightfoot 2006; Xiao, Zhao 2009; Zhang 2001), agglomeration effects (Chen, Stough 2006; Cheng, Kwan 2000; Kuo, Huang 2003; Sun et al. 2002; Wei et al. 2005; Xiao, Zhao 2009; Zhou et al. 2002), and infrastructure (Xiao, Zhao 2009; Zhang 2001). Empirical research has shown that labor quality displays a larger effect on FDI (Chen, Stough 2006; Cheng, Kwan 2000; Na, Lightfoot 2006). Wei et al. (2005) and Zhou et al. (2002) focused on the effects of GDP on FDI location choice in China. Also important are determinants of 
government policies on foreign investment (Zhou et al. 2002) and government incentives towards foreign investment (Chen, Stough 2006; Cheng, Kwan 2000). Luo (2000) provided a framework for FDI-related location determinants in China, and this framework is applicable in general to such matters as FDI processes or specifically to such matters as expanding markets. His framework consists of five groups of factors: cost/tax factors, demand factors, macro-economic factors, socio-political factors, and strategic factors.

\subsection{Fuzzy analytic network process (FANP)}

The analytic hierarchy process (AHP) is a powerful tool for dealing with complex multi-criteria decision-making problems, and can help to establish decision models that account for both qualitative and quantitative components. The AHP represents a framework with unidirectional relationships among elements of a system, which implies that lower levels do not affect upper levels (Saaty 1980). The analytic network process (ANP) - also introduced by Saaty - is the generic form of the AHP. The ANP does not require hierarchical structure, because it replaces the hierarchy in the AHP with a network incorporating feedback and interdependent relationships among elements. Not only does the importance of the criteria determine the importance of the alternatives as in a hierarchy; the importance of the alternatives may also affect the importance of the criteria (Saaty 2006). The ANP provides a general framework for dealing with decisions without generating assumptions about the independence between levels of a hierarchy (Saaty 2005). Human sometimes lack the ability to make decisions rigorously because the problem at hand is too complex to be understood. They often find solutions by rules of thumb or through heuristic thinking based on binary logic. However, real life is filled with uncertainty by its very nature. Regarding a situation or a system related particularly to human factors and to human thought, evaluations relying on absolute perspectives yield results that prove inadequate in reflecting the reality of that situation or that system. Therefore, fuzzy logic with fuzzy numbers is useful in analyzing the processes of human judgment to eliminate vagueness, subjectivity, and imprecision. Mikhailov and Singh (1999) conducted a comparative study on traditional crisp values and fuzzy intervals, and found that fuzzy measures perform better than crisp values. The FANP method has been applied in a variety of fields (Liou et al. 2011; Yu, Cheng 2007; Yüksel, Dağdeviren 2010). An additional method, like SWOT, is used with ANP and FANP. Mohammad et al. (2011) develop an integrated model based on SWOT, ANP, and VIKOR to prioritize the strategies of the Iranian mining sector. In the work of Foroughi et al. (2012), the research model was used to design an ANP by using the SWOT matrix to develop priorities and strategies at the Islamic Azad University of Naragh branch. Sevkli et al. (2012) proposed the SWOT-FANP method, which was implemented and tested for the Turkish airline industry.

\subsection{Summary}

This paper summarizes determinants that influence the location selection of FDI in China (Appendix A). These are comprehensive factors involving international location decisions. However, not all determinants are relevant to each enterprise, as there may be only a few 
important factors that dominate the decisions in each business. Many of these determinants are industry-specific. The preliminary assessment criteria consist of the aforementioned location determinants, and we add new criteria based on industry characteristics for the biotech pharmaceutical industry in relation to focus group discussion (FGD). SWOT's main weakness is an overall dependence on a qualitative analysis that merely ranks the importance of individual factors without quantitatively measuring them. The SWOTFANP method not only combines both qualitative and quantitative information, but also deals with complex problems involving interactions among various factors and removes ambiguities. This method should not only identify important factors, such as strength, weakness, opportunity, and threat, and help rank them according to importance, but it should also rank the alternative strategies according to their level of competitiveness for decision-makers. However, the results cannot help provide enterprises realize their position in the competition and have a reference for developing strategies. Thus, this paper applies a new hybrid method based on a combination of SWOT-FANP with GSM, which serves as an analytic tool and suitably provides solutions in complex multi-criteria decision-making environments, and show the competition situation on a quadrant coordinate to reveal enterprises' competitive position.

\section{Methodology}

\subsection{Model structure}

The paper presents multinational pharmaceutical enterprises. First, we held a FGD with five experts that had more than 15 years of experience in the identified pharmaceutical enterprise and had roles as a marketing and sales director, a general manager and a manager to determine the preliminary criteria belonging to strength, weakness, opportunity and threat categories and second-tier cities according to (1) a literature review and (2) experts who got involved in this study to finalize, verify, and validate the criteria. Next, we identified and determined key criteria that influence the decision according to the same group of experts. Sequentially, we choose the three most important criteria within each SWOT group to keep the number of pair-wise comparisons at a manageable level and selected five second-tier cities: Chongqing, Chengdu, Wuhan, Suzhou, and Xian. Finally, we developed the grand strategy matrix based on SWOTand international-strategy alternatives based on these criteria (Fig.1). Appendix B presents the corresponding detailed definitions for each criterion and each alternative. Figure 2 shows a hierarchy SWOT-ANP model with symbols. This framework is divided into four levels. The first level is the goal. Groups within SWOT are listed in the second level. Each group includes more criteria that are on the third level. The fourth level consists of five alternatives. The hierarchical model depicts a situation where there is no interaction among the alternatives, while the loop diagram indicates a situation where there is interaction within criteria. 


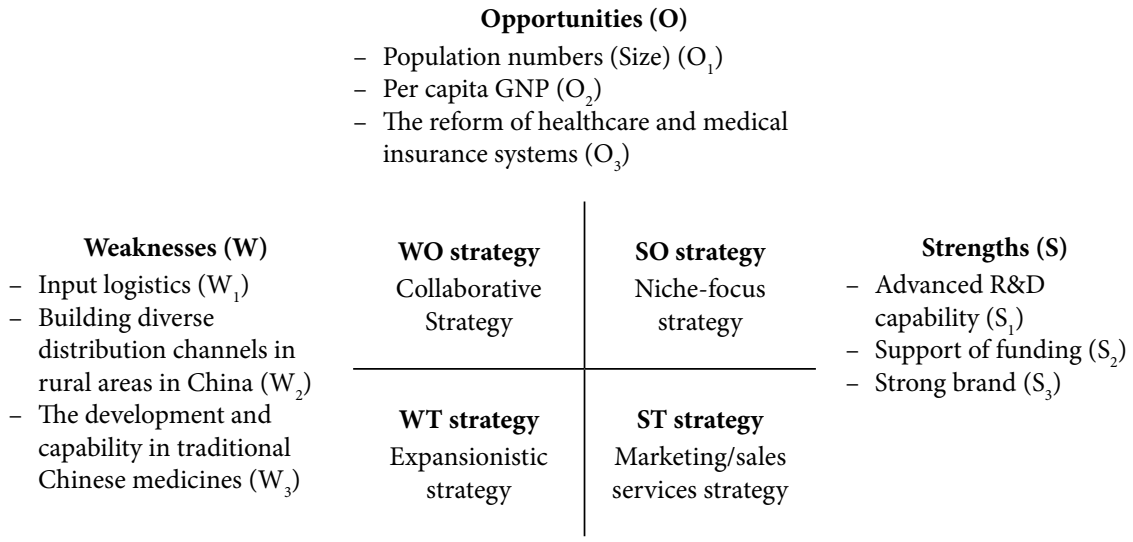

Threats (T)

- Government regulation of drug launches $\left(\mathrm{T}_{1}\right)$

- Highly intensive competition $\left(\mathrm{T}_{2}\right)$

- Government corruption $\left(\mathrm{T}_{3}\right)$

Fig. 1. The grand strategy matrix based on SWOT

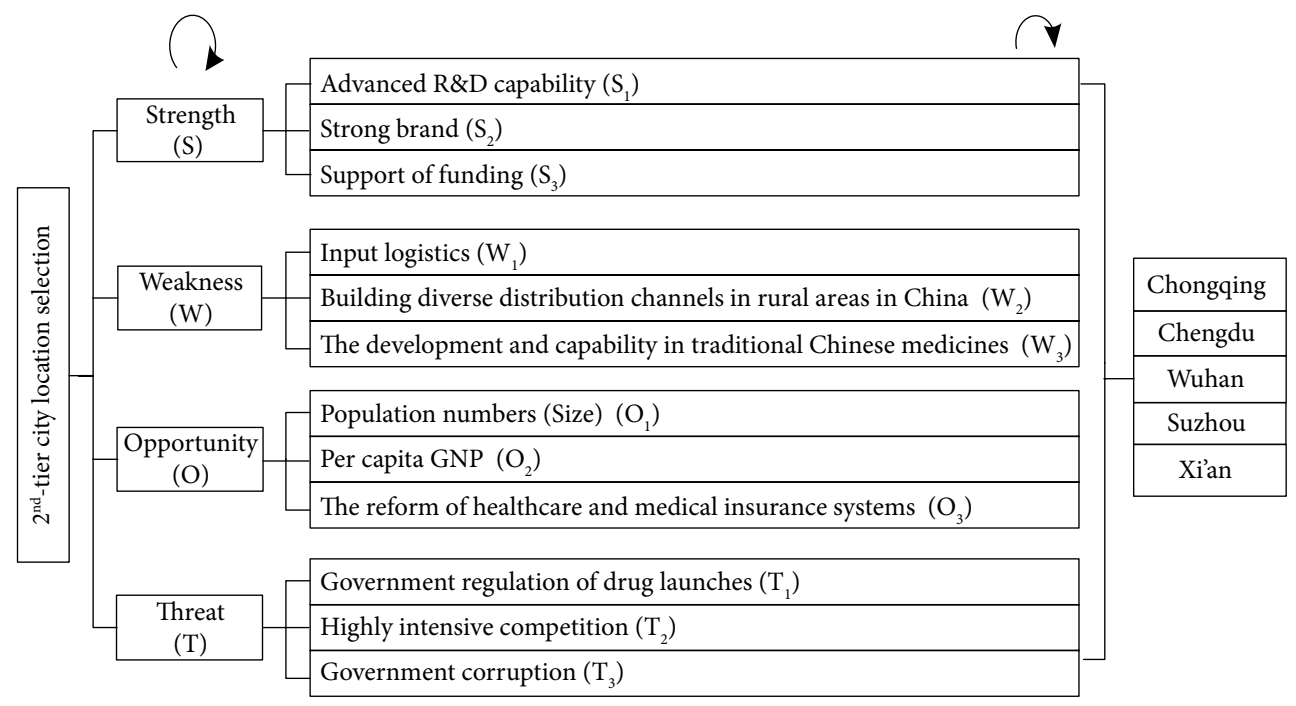

Fig. 2. A SWOT-ANP model for $2^{\text {nd }}$-tier city location selection

\subsection{Concept application}

Two main discussions were designed for the same group of experts. One part is related to pair-wise comparisons among the group and within the criteria. We apply fuzzy logic to measure weights for pair-wise comparisons. 


\subsubsection{Fuzzy numbers and research method}

As mentioned above, humans are often unable to make rigorous judgments because of the complexity of the matter at hand. Traditional multiple-attribute decision-making methods cannot effectively handle problems characterized by imprecision and vagueness. To resolve this issue, Zadeh (1965) introduced the fuzzy set theory, which served to illustrate the fuzzy phenomena that occur in human activities. The theory's function was to convert human behaviors and conceptual languages into fuzzy numbers using the uncertain elements of a fuzzy set membership. These fuzzy numbers can be calculated and ranked.

The fuzzy sets are defined in terms of membership functions. Membership functions relative to $X$ represent fuzzy subsets of $X$. The membership function representing a fuzzy set is usually denoted by $\mu_{A}$. For an element $x$ of $X$, the value $\mu_{A}(x)$ is called the membership degree of $x$ in the fuzzy set. This function assigns to each element $\mathrm{x}$ of the universal set $\mathrm{X}$ a number $\mu_{A}(x)$ in the unit interval $[0,1]$. The membership degree $\mu_{A}(x)$ quantifies the membership grade of the element $x$ to the fuzzy set. An element $x$ really belongs to A if $\mu_{A}(x)=1$ but clearly does not if $\mu_{A}(x)=0$.

A triangular fuzzy number can be denoted by three real numbers $(l, m, u)$. The parameters $l, m$, and $u$ respectively stand for the smallest possible value, the most promising value, and the largest possible value. Its membership function can be defined as:

$$
(d)=\left\{\begin{array}{ll}
1, & \text { if } m_{2} \geq m_{1}, \\
0, & \text { if } l_{1} \geq u_{2}, \\
\frac{l_{1}-u_{2}}{\left(m_{2}-u_{2}\right)-\left(m_{1}-l_{1}\right)}, & \text { otherwise, }
\end{array}\right\} .
$$

(a) Chang's method has been applied in this study. Let $\mathrm{X}=\left\{x_{1}, x_{2}, \ldots, x_{n}\right\}$ be an object set, and $\mathrm{U}=\left\{u_{1}, u_{2}, \ldots, u_{n}\right\}$ be a goal set. According to Chang's $(1992,1996)$ extent-analysis method, each object is taken and an extent analysis for each goal $\left(g_{i}\right)$ is performed. Therefore, $m$ extent analysis values for each object can be obtained with the following signs:

$$
M_{g_{i}}^{1}, M_{g_{i}}^{2}, \ldots, M_{g_{i}}^{m}, \quad i=1,2, \ldots, n,
$$

where all the $M_{g_{i}}^{j}(j=1,2, \ldots, n)$ are TFNs. The steps of Chang's extent analysis can be given as in the following:

Step 1: The value of fuzzy synthetic extent with respect to the $i^{\text {th }}$ object is defined as:

$$
S_{j}=\sum_{j=1}^{m} M_{g_{i}}^{j} \otimes\left[\sum_{i=1}^{n} \sum_{j=1}^{m} M_{g_{i}}^{j}\right]^{-1}
$$

To obtain $\sum_{j=1}^{m} M_{g_{i}}^{j}$, perform the fuzzy addition operation of $\mathrm{m}$ extent analysis relative to values for a particular matrix such that:

$$
\sum_{j=1}^{m} M_{g_{i}}^{j}=\left(\sum_{j=1}^{m} l_{j}, \sum_{j=1}^{m} m_{j}, \sum_{j=1}^{m} u_{j}\right)
$$


and to obtain $\left[\sum_{i=1}^{n} \sum_{j=1}^{m} M_{g_{i}}^{j}\right]^{-1}$, perform the fuzzy addition operation of $M_{g_{i}}^{j}(j=1,2, \ldots, m)$ values such that:

$$
\sum_{i=1}^{n} \sum_{j=1}^{m} M_{g_{i}}^{j}=\left(\sum_{j=1}^{m} l_{i}, \sum_{j=1}^{m} m_{i}, \sum_{j=1}^{m} u_{i}\right)
$$

and then compute the inverse of the vector in Eq. (4) such that:

$$
\left[\sum_{i=1}^{n} \sum_{j=1}^{m} M_{g_{i}}^{j}\right]^{-1}=\left(\frac{1}{\sum_{i=1}^{n} u_{i}}, \frac{1}{\sum_{i=1}^{n} m_{i}}, \frac{1}{\sum_{i=1}^{n} l_{i}}\right) .
$$

Step 2: The degree of the possibility of $M_{2}=\left(l_{2}, m_{2}, u_{2}\right) \geq M_{1}\left(l_{1}, m_{1}, u_{1}\right)$ is defined as $V\left(M_{2} \geq M_{1}\right)=\sup _{y \geq x}\left[\min \left(u_{M_{1}}(x), u_{M_{2}}(y)\right)\right]$ and can be equivalently expressed as follows:

$$
V\left(M_{2} \geq M_{1}\right)=\operatorname{hgt}\left(M_{1} \cap M_{2}\right)=u_{M_{2}}(d)=\left\{\begin{array}{ll}
1, & \text { if } m_{2} \geq m_{1}, \\
0, & \text { if } l_{1} \geq u_{2}, \\
\frac{l_{1}-u_{2}}{\left(m_{2}-u_{2}\right)-\left(m_{1}-l_{1}\right)}, \text { else, }
\end{array}\right\},
$$

where $d$ is the ordinate of the highest intersection point $\mathrm{D}$ between $u_{M_{1}}$ and $u_{M_{2}}$.

To compare $M_{1}$ and $M_{2}$, we need both the values of $V\left(M_{1} \geq M_{2}\right)$ and $V\left(M_{2} \geq M_{1}\right)$. This is given in Figure 3.

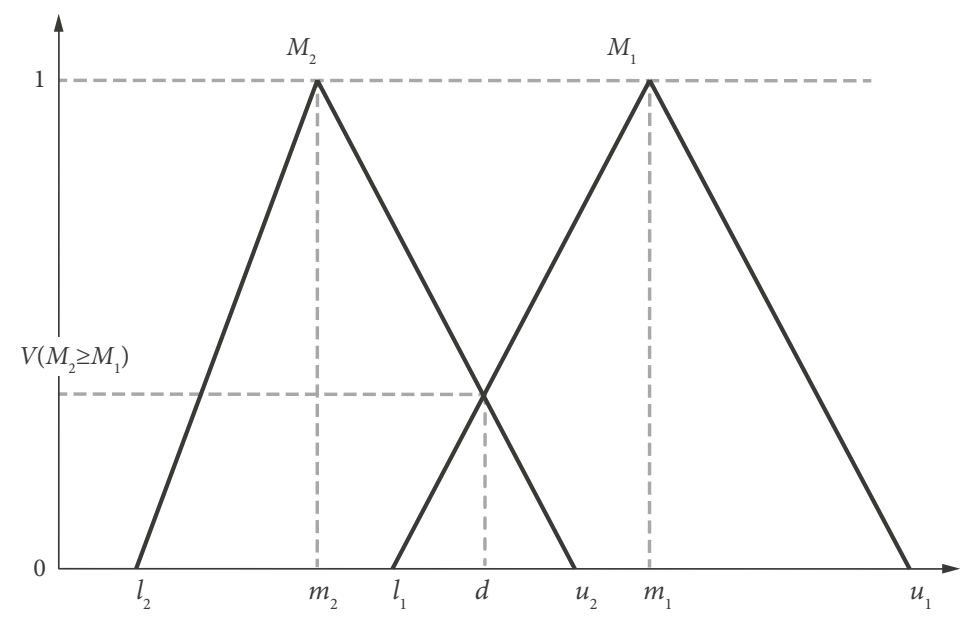

Fig. 3. Intersection of $M_{1}$ and $M_{2}$ 
Step 3: The degree possibility for a convex fuzzy number to be greater than $k$ convex fuzzy numbers $M_{i}(i=1,2, \ldots, k)$ can be defined by:

$$
\begin{aligned}
V(M & \left.\geq M_{1}, M_{2}, \ldots, M_{k}\right)=V\left[\left(M \geq M_{1}\right) v e\left(M \geq M_{2}\right) \text { and } \ldots \text { and }\left(M \geq M_{k}\right)\right]= \\
& \min V\left(M \geq M_{i}\right), \quad i=1,2, \ldots, k .
\end{aligned}
$$

Assume that:

$$
d^{\prime}\left(A_{i}\right)=\min V\left(S_{i} \geq S_{k}\right)
$$

For $k=1,2, \ldots, n ; k \neq i$. Then the weight vector is given by:

$$
W^{\prime}=\left(d^{\prime}\left(A_{1}\right), d^{\prime}\left(A_{2}\right), \ldots, d^{\prime}\left(A_{n}\right)\right)^{T}
$$

where $A_{i}(i=1,2, \ldots, n)$ are $n$ elements.

Step 4: Via normalization, the normalized weight vectors are:

$$
W=\left(d\left(A_{1}\right), d\left(A_{2}\right), \ldots, d\left(A_{n}\right)\right)^{T},
$$

where $W$ is a nonfuzzy number.

\subsubsection{Normalize the score of the alternative as regards the key criteria}

The experts are asked to rank the score of the alternative with regards to the key criteria using a 1-5 scale. We used the following concept to normalize the score of the alternative with regards to the key criteria and determined the benchmarking value (Deng 2000).

(1) Benefit-criteria normalization (the higher the better):

$$
r_{i j}=\frac{p_{i j}}{\max _{j} p_{i j}}, \forall_{j},
$$

e.g.

$$
p_{11}=2, p_{12}=4, p_{13}=5, p_{14}=3 \text {, }
$$

then

$$
r_{11}=\frac{p_{11}}{\max _{j} p_{1 j}}=\frac{2}{5}=0.4,
$$

and similarly

$$
r_{12}=0.8, r_{13}=1.0, r_{14}=0.6 \text {. }
$$

(2) Cost-criteria normalization (the lower the better):

$$
\begin{aligned}
& r_{i j}=\frac{\max _{j} p_{i j}}{p_{i j}}, \forall, \\
& \text { e.g. } \\
& p_{11}=2, p_{12}=4, p_{13}=5, p_{14}=3,
\end{aligned}
$$


then

$$
r_{11}=\frac{\max _{j} p_{i j}}{p_{i j}}=\frac{2}{2}=1.0,
$$

and similarly

$$
r_{12}=0.5, r_{13}=0.4, r_{14}=0.67 \text {. }
$$

(3) Moderation-criteria normalization (the more moderate the better):

$$
r_{i j}=\frac{\min \left\{p_{i j}, p_{o}\right\}}{\max \left\{p_{i j}, p_{o}\right\}},
$$

where

$$
p_{o}=\frac{1}{n} \sum_{j=1}^{n} p_{i j} \text {, }
$$

e.g.

$$
p_{11}=2, p_{12}=4, p_{13}=5, p_{14}=3 \text {, }
$$

then

$$
\begin{aligned}
& p_{o}=\frac{1}{4} \sum_{j=1}^{4} p_{i j}=\frac{1}{4}(2+4+5+3)=3.5 ; \\
& r_{i j}=\frac{\min \left\{p_{11}, p_{o}\right\}}{\max \left\{p_{11}, p_{o}\right\}}=\frac{\min \{2,3.5\}}{\max \{2,3.5\}}=\frac{2}{3.5}=0.57,
\end{aligned}
$$

and similarly

$$
p_{11}=0.88, p_{13}=0.7, p_{14}=0.86 \text {. }
$$

This paper suggests that the benchmarking value can be determined using the geometric mean. To calculate and compare the coordinate values of internal and external assessments and then show them on the four-quadrant coordinate. Firstly, the internal and external scores of the compared enterprises should be added together and then the benchmarking value must be subtracted. The final value will be the coordinate value of the compared enterprise in theSWOT analysis matrix. The coordinate value will be within -1 to +1 . The enterprise possesses strengths andopportunities when the coordinate value is larger than the benchmarking value, but the enterprise is comparativelyweak and faces threats when the coordinate value is smaller than the benchmarking value:

$$
\begin{array}{ll}
I C_{j}=I_{j}-I B & j=1,2, \ldots, n ; \\
E C_{j}=E_{j}-E B & j=1,2, \ldots, n,
\end{array}
$$

where $I C_{j}$ - the internal assessment coordinate value of the $j^{\text {th }}$ enterprise.

$I_{j}$ - internal assessment score of the $j^{\text {th }}$ enterprise. 
$I B$ - benchmerking value of the internal assessment.

$E C_{j}$ - the external assessment coordinate value of the $j^{\text {th }}$ enterprise.

$E_{j}$ - external assessment score of the $j^{\text {th }}$ enterprise.

$E B$ - benchmerking value of the external assessment.

$-1 \leq I C_{j} \leq+1$;

$-1 \leq E C_{j} \leq+1$.

By calculating the benchmarking and coordinate values according to the above formulas, two groups ofdata can be obtained: one is the coordinate value used to compare the internal assessment of the enterprises; theother is the coordinate used to compare the external assessment of the enterprises. To show the comparisonon the four-quadrant coordinate, the ordinate denotes the external environment (opportunities and threats), while the abscissa denotes the internal environment (strengths and weaknesses). Now, each enterprise has a coordinate $(\mathrm{x}, \mathrm{y})$, so its position in the competition can be clearly realized. This can help theenterprises assess themselves as well as the components more effectively and may be used as the foundation for development policies (Giachetti, Young 1997).

\section{Results and discussion}

\subsection{Determining the local weights of SWOT groups with respect to the goal}

In this step, four assessment groups were compared with each other with respect to the goal. The pair-wise comparisons rest on FGD (with a scale ranging from 1 to 9). Then, the pairwise comparison matrices were formed with a fuzzy scale. The fuzzy scale regarding relative importance to measure the relative weights can be seen in Table 1 . With fuzzy values, the local weights of each assessment group were obtained, as shown in Table 2.

Table 1. Linguistic scales for the importance weight

\begin{tabular}{ccc}
\hline $\begin{array}{c}\text { Linguistic scales for } \\
\text { importance degree }\end{array}$ & Linguistic terms & Linguistic values \\
\hline 1 & Equal importance (EI) & $(1,1,1)$ \\
3 & Moderate importance (MI) & $(2,3,4)$ \\
5 & Strong importance (SI) & $(4,5,6)$ \\
7 & Very strong importance (VI) & $(6,7,8)$ \\
9 & Absolute importance (AI) & $(8,9,9)$ \\
2 & & $(1,2,3)$ \\
4 & & $(3,4,5)$ \\
6 & Intermediate values & $(5,6,7)$ \\
8 & & $(7,8,9)$ \\
\hline
\end{tabular}


Table 2. Pair-wise comparison matrix and weights of SWOT groups

\begin{tabular}{cccccc}
\hline Dimensions & $\mathrm{S}$ & $\mathrm{W}$ & $\mathrm{O}$ & $\mathrm{T}$ & $\mathrm{W}_{\text {swoT(local) }}$ \\
\hline $\mathrm{S}$ & $(1,1,1)$ & $(1,1,2)$ & $(1,1,2)$ & $(1,1,2)$ & 0.25 \\
$\mathrm{~W}$ & $(0.5,1,1)$ & $(1,1,1)$ & $(1,1,2)$ & $(1,1,2)$ & 0.25 \\
$\mathrm{O}$ & $(0.5,1,1)$ & $(0.5,1,1)$ & $(1,1,1)$ & $(1,1,2)$ & 0.25 \\
$\mathrm{~T}$ & $(0.5,1,1)$ & $(0.5,1,1)$ & $(0.5,1,1)$ & $(1,1,1)$ & 0.25 \\
\hline
\end{tabular}

\subsection{Determining the inner dependence matrix among SWOT groups and calculating the global weights of SWOT groups}

This paper assumes the assessment groups to be dependent. Therefore, the impact of each group is analyzed on all other groups by using pair-wise comparisons. According to the FGD serving to identify the inner loops among the groups, there are relations between groups, and four pair-wise comparison matrices for the groups based on inner dependencies were formed. An example of group comparisons is the strength-versus-weakness comparison using the question, "How important is a strength when it is compared with a weakness?" The resulting relative-importance weights in terms of these inner-dependence matrices are calculated (see Table 3 through Table 6, separately for each group).

Then, by multiplying the overall-dependence matrixes of the groups with the local weights of the groups, the global weights of the SWOT groups are obtained. Here the values for S, $\mathrm{W}, \mathrm{O}$, and $\mathrm{T}$ changed from 0.25 to $0.393,0.25$ to $0.182,0.25$ to 0.295 , and 0.25 to 0.175 , respectively. To represent a competitive position of second-tier cities in the coordinate plot, we integrated SWOT into the external (opportunities and threats) and internal (strengths and weaknesses) environments. Finally, the global weights for $\mathrm{S}, \mathrm{W}, \mathrm{O}$, and $\mathrm{T}$ are $0.684,0.316$, 0.627 , and 0.373 , respectively:

$$
\mathrm{W}_{\text {SWOT(global) }}=\left[\begin{array}{llll}
0.484 & 0.439 & 0.308 & 0.343 \\
0.157 & 0.329 & 0.000 & 0.241 \\
0.309 & 0.000 & 0.692 & 0.000 \\
0.051 & 0.233 & 0.000 & 0.416
\end{array}\right]\left[\begin{array}{l}
0.25 \\
0.25 \\
0.25 \\
0.25
\end{array}\right]=\left[\begin{array}{l}
0.393 \\
0.182 \\
0.295 \\
0.175
\end{array}\right] .
$$

Table 3. The relative-importance weights for the "S" group

\begin{tabular}{cccccc}
\hline $\mathrm{S}$ & $\mathrm{S}$ & $\mathrm{W}$ & $\mathrm{O}$ & $\mathrm{T}$ & $\begin{array}{c}\text { Relative-importance } \\
\text { weights }\end{array}$ \\
\hline $\mathrm{S}$ & $(1,1,1)$ & $(1,2,3)$ & $(2,3,4)$ & $(2,3,4)$ & 0.484 \\
$\mathrm{~W}$ & $(0.333,0.5,1)$ & $(1,1,1)$ & $(0.333,0.5,1)$ & $(1,1,2)$ & 0.157 \\
$\mathrm{O}$ & $(0.25,0.333,0.5)$ & $(1,2,3)$ & $(1,1,1)$ & $(1,2,3)$ & 0.309 \\
$\mathrm{~T}$ & $(0.25,0.333,0.5)$ & $(0.5,1,1)$ & $(0.333,0.5,1)$ & $(1,1,1)$ & 0.051 \\
\hline
\end{tabular}


Table 4. The relative-importance weights for the "W" group

\begin{tabular}{ccccc}
\hline $\mathrm{W}$ & $\mathrm{S}$ & $\mathrm{W}$ & $\mathrm{T}$ & $\begin{array}{c}\text { Relative-importance } \\
\text { weights }\end{array}$ \\
\hline $\mathrm{S}$ & $(1.000,1.000,1.000)$ & $(1.000,1.000,2.000)$ & $(1.000,1.000,2.000)$ & 0.439 \\
$\mathrm{~W}$ & $(0.500,1.000,1.000)$ & $(1.000,1.000,1.000)$ & $(1.000,1.000,2.000)$ & 0.329 \\
$\mathrm{~T}$ & $(0.333,0.500,1.000)$ & $(0.500,1.000,1.000)$ & $(1.000,1.000,1.000)$ & 0.233 \\
\hline
\end{tabular}

Table 5. The relative-importance weights for the "O" group

\begin{tabular}{cccc}
\hline $\mathrm{O}$ & $\mathrm{S}$ & $\mathrm{O}$ & Relative-importance weights \\
\hline $\mathrm{S}$ & $(1.000,1.000,1.000)$ & $(0.333,0.500,1.000)$ & 0.308 \\
$\mathrm{O}$ & $(1.000,2.000,3.000)$ & $(1.000,1.000,1.000)$ & 0.692 \\
\hline
\end{tabular}

Table 6. The relative-importance weights for the "T" group

\begin{tabular}{ccccc}
\hline $\mathrm{T}$ & $\mathrm{S}$ & $\mathrm{W}$ & $\mathrm{T}$ & $\begin{array}{c}\text { Relative-importance } \\
\text { weights }\end{array}$ \\
\hline $\mathrm{S}$ & $(1.000,1.000,1.000)$ & $(1.000,1.000,2.000)$ & $(1.000,1.000,2.000)$ & 0.343 \\
$\mathrm{~W}$ & $(0.500,1.000,1.000)$ & $(1.000,1.000,1.000)$ & $(0.333,0.500,1.000)$ & 0.241 \\
$\mathrm{~T}$ & $(0.500,1.000,1.000)$ & $(1.000,2.000,3.000)$ & $(1.000,1.000,1.000)$ & 0.416 \\
\hline
\end{tabular}

\subsection{Calculating the global weights of each criteria}

In this step, we first used a pair-wise comparison to calculate the local weight of each factor within corresponding group uses. The detailed pair-wise comparison matrices are shown in Table 7 through Table 10. Moreover, the FGD serves to identify the inner loops among the criteria in each group. There are no relations between the criteria in all groups, except in the $S$ group, in which the resulting relative importance weights of the dependence matrix are calculated. Then, by multiplying the dependence matrix of the criteria with the local weights of the criteria, the criteria's interdependent weights in the S group were formed, the equation of which is as follows. Next, we multiplied the global weights for the SWOT groups obtained above with the corresponding global weights of the corresponding criteria, and the last column in Table 11 shows the computed results for all criteria.

$$
\mathrm{W}_{\mathrm{s}(\text { global })}=\left[\begin{array}{lll}
0.308 & 0.449 & 0.290 \\
0.692 & 0.351 & 0.436 \\
0.000 & 0.200 & 0.274
\end{array}\right]\left[\begin{array}{l}
0.439 \\
0.329 \\
0.233
\end{array}\right]=\left[\begin{array}{l}
0.350 \\
0.521 \\
0.129
\end{array}\right] .
$$

Table 7. Pair-wise comparison matrices and local weights for "S"-group factors

\begin{tabular}{ccccc}
\hline $\mathrm{S}$ & $\mathrm{S}_{1}$ & $\mathrm{~S}_{2}$ & $\mathrm{~S}_{3}$ & $\mathrm{~W}_{\text {s(local) }}$ \\
\hline $\mathrm{S}_{1}$ & $(1.000,1.000,1.000)$ & $(1.000,1.000,2.000)$ & $(1.000,2.000,3.000)$ & 0.439 \\
$\mathrm{~S}_{2}$ & $(0.500,1.000,1.000)$ & $(1.000,1.000,1.000)$ & $(1.000,1.000,2.000)$ & 0.329 \\
$\mathrm{~S}_{3}$ & $(0.333,0.500,1.000)$ & $(0.500,1.000,1.000)$ & $(1.000,1.000,1.000)$ & 0.233 \\
\hline
\end{tabular}


Table 8. Pair-wise comparison matrices and local weights for "W"-group factors

\begin{tabular}{ccccc}
\hline $\mathrm{W}$ & $\mathrm{W}_{1}$ & $\mathrm{~W}_{2}$ & $\mathrm{~W}_{3}$ & $\mathrm{~W}_{\mathrm{W}(\text { local }}$ \\
\hline $\mathrm{W}_{1}$ & $(1.000,1.000,1.000)$ & $(1.000,2.000,3.000)$ & $(1.000,1.000,2.000)$ & 0.415 \\
$\mathrm{~W}_{2}$ & $(0.333,0.500,1.000)$ & $(1.000,1.000,1.000)$ & $(0.250,0.330,0.500)$ & 0.092 \\
$\mathrm{~W}_{3}$ & $(0.500,1.000,1.000)$ & $(2.000,3.030,4.000)$ & $(1.000,1.000,1.000)$ & 0.493 \\
\hline
\end{tabular}

Table 9. Pair-wise comparison matrices and local weights for "O"-group factors

\begin{tabular}{ccccc}
\hline $\mathrm{O}$ & $\mathrm{O}_{1}$ & $\mathrm{O}_{2}$ & $\mathrm{O}_{3}$ & $\mathrm{~W}_{\text {O(local) }}$ \\
\hline $\mathrm{O}_{1}$ & $(1.000,1.000,1.000)$ & $(0.500,1.000,1.000)$ & $(0.500,0.670,1.000)$ & 0.247 \\
$\mathrm{O}_{2}$ & $(0.500,1.000,2.000)$ & $(1.000,1.000,1.000)$ & $(0.500,0.670,1.000)$ & 0.308 \\
$\mathrm{O}_{3}$ & $(1.000,1.500,2.000)$ & $(1.000,1.500,2.000)$ & $(1.000,1.000,1.000)$ & 0.445 \\
\hline
\end{tabular}

Table 10. Pair-wise comparison matrices and local weights for "T"-group factors

\begin{tabular}{ccccc}
\hline $\mathrm{T}$ & $\mathrm{T}_{1}$ & $\mathrm{~T}_{2}$ & $\mathrm{~T}_{3}$ & $\mathrm{~W}_{\text {T(local) }}$ \\
\hline $\mathrm{T}_{1}$ & $(1.000,1.000,1.000)$ & $(0.500,1.000,1.000)$ & $(1.000,1.500,2.000)$ & 0.365 \\
$\mathrm{~T}_{2}$ & $(0.500,1.000,2.000)$ & $(1.000,1.000,1.000)$ & $(0.500,1.000,1.000)$ & 0.334 \\
$\mathrm{~T}_{3}$ & $(0.500,0.670,1.000)$ & $(0.500,1.000,2.000)$ & $(1.000,1.000,1.000)$ & 0.302 \\
\hline
\end{tabular}

Table 11. The computed results for all criteria

\begin{tabular}{cccccc}
\hline Group & $\mathrm{W}_{\text {SWOT(global) }}$ & Criteria & $\mathrm{W}_{\text {Criteria (local) }}$ & $\mathrm{W}_{\text {Criteria (dependence) }}$ & $\mathrm{W}_{\text {Criteria (global) }}$ \\
\hline $\mathrm{S}$ & 0.684 & $\mathrm{~S}_{1}$ & 0.439 & 0.350 & 0.239 \\
& & $\mathrm{~S}_{2}$ & 0.329 & 0.521 & 0.356 \\
& & $\mathrm{~S}_{3}$ & 0.233 & 0.333 & 0.088 \\
$\mathrm{~W}$ & \multirow{2}{*}{0.316} & $\mathrm{~W}_{1}$ & 0.415 & & 0.131 \\
& & $\mathrm{~W}_{2}$ & 0.092 & & 0.029 \\
& & $\mathrm{~W}_{3}$ & 0.493 & & 0.156 \\
\hline $\mathrm{O}$ & 0.627 & $\mathrm{O}_{1}$ & 0.247 & & 0.155 \\
& & $\mathrm{O}_{2}$ & 0.308 & & 0.193 \\
& & $\mathrm{O}_{3}$ & 0.445 & & 0.279 \\
$\mathrm{~T}$ & 0.373 & $\mathrm{~T}_{1}$ & 0.368 & & 0.136 \\
& & $\mathrm{~T}_{2}$ & 0.334 & & 0.124 \\
& & $\mathrm{~T}_{3}$ & 0.302 & & 0.112 \\
\hline
\end{tabular}

\subsection{Obtaining the matrix of the second-tier city in China under SWOT analysis}

In this step, the score of the alternative with regards to the criteria, which is ranked by experts in a 1-5 scale, is determined. To unify the scale and the direction of the criteria, normalizing the criteria is necessary. By multiplying the global weights of the criteria from the FANP method based on FGD with the total weights with criteria performance after normalization, the total weight scoreare shown in Table 12. Finally, the coordinate value of strengths (S), 
weaknesses $(\mathrm{W})$, opportunities $(\mathrm{O})$, and threats $(\mathrm{T})$ can be obtained by subtracting the benchmarking value from the total weight score (see Table 13). By calculating coordinative values of internal and external criteria, Figure 4 not only presents clearly the competitive position of second-tier cities, but also helps the enterprise choose the strategy for development. As can be seen in Figure 4, Chongqing and Suzhou cities are in the first quadrant. These two cities are in the best competitive positionas a result of having external opportunities for development and internal competing strength. Chengdu and Wuhan are in the third quadrant, and Xian is in the fourth quadrant.

Table 12. Internal and external criteria weighted average score of $2^{\text {nd }}$-tier cities in China

\begin{tabular}{ccccccc}
\hline \multirow{2}{*}{ Internal criteria } & weight & \multicolumn{5}{c}{$2^{\text {nd }}$-tier cities } \\
\cline { 3 - 7 } & & $\mathrm{A}_{1}$ & $\mathrm{~A}_{2}$ & $\mathrm{~A}_{3}$ & $\mathrm{~A}_{4}$ & $\mathrm{~A}_{5}$ \\
\hline $\mathrm{S}_{1}$ & 0.239 & 4.682 & 3.955 & 4.205 & 4.841 & 4.659 \\
$\mathrm{~S}_{2}$ & 0.356 & 4.818 & 3.432 & 4.432 & 4.886 & 4.705 \\
$\mathrm{~S}_{3}$ & 0.088 & 4.727 & 4.568 & 4.591 & 4.841 & 4.636 \\
$\mathrm{~W}_{1}$ & 0.131 & 4.180 & 5.320 & 4.500 & 4.000 & 4.400 \\
$\mathrm{~W}_{2}$ & 0.029 & 3.880 & 5.220 & 4.110 & 4.320 & 4.210 \\
$\mathrm{~W}_{3}$ & 0.156 & 3.530 & 4.560 & 4.350 & 3.500 & 3.910 \\
\hline Weighted average value & 1.000 & 4.466 & 4.133 & 4.378 & 4.508 & 4.510 \\
\hline \multirow{2}{*}{ External criteria } & weight & & & $2^{\text {nd }}$-tier cities & & \\
\cline { 3 - 7 } & 0.155 & 5.341 & 4.591 & 4.659 & 4.932 & 4.818 \\
\hline $\mathrm{O}_{1}$ & 0.193 & 4.614 & 4.068 & 4.000 & 4.432 & 4.500 \\
$\mathrm{O}_{2}$ & 0.279 & 4.070 & 3.910 & 3.700 & 4.930 & 3.730 \\
$\mathrm{O}_{3}$ & 0.136 & 4.341 & 4.460 & 4.045 & 4.023 & 4.110 \\
$\mathrm{~T}_{1}$ & 0.124 & 4.455 & 4.591 & 4.140 & 4.200 & 4.432 \\
$\mathrm{~T}_{2}$ & 0.112 & 4.932 & 4.841 & 4.545 & 4.432 & 4.340 \\
$\mathrm{~T}_{3}$ & 1.000 & 4.554 & 4.310 & 4.103 & 4.564 & 4.255 \\
\hline Weighted average value & & & & &
\end{tabular}

Table 13. Coordinate values of $2^{\text {nd }}$-tier cities in China under SWOT analysis

\begin{tabular}{lcccccc}
\hline & \multicolumn{5}{c}{$2^{\text {nd }}$-tier cities } & \multirow{2}{*}{$\begin{array}{c}\text { Benchmarking } \\
\text { value }\end{array}$} \\
\cline { 2 - 6 } & $\mathrm{A}_{1}$ & $\mathrm{~A}_{2}$ & $\mathrm{~A}_{3}$ & $\mathrm{~A}_{4}$ & $\mathrm{~A}_{5}$ & 4.400 \\
\hline $\begin{array}{l}\text { Weighted average value } \\
\text { of internal criteria }\end{array}$ & 4.466 & 4.133 & 4.378 & 4.508 & 4.510 & \\
$\begin{array}{l}\text { Coordinate value of } \\
\text { internal criteria }\end{array}$ & 0.066 & -0.267 & -0.021 & 0.123 & 0.110 & 4.354 \\
$\begin{array}{l}\text { Weighted average value } \\
\text { of external criteria }\end{array}$ & 4.554 & 4.310 & 4.103 & 4.564 & 4.255 & \\
$\begin{array}{l}\text { Coordinate value of } \\
\text { internal criteria }\end{array}$ & 0.200 & -0.043 & -0.250 & 0.210 & -0.099 & \\
\hline
\end{tabular}




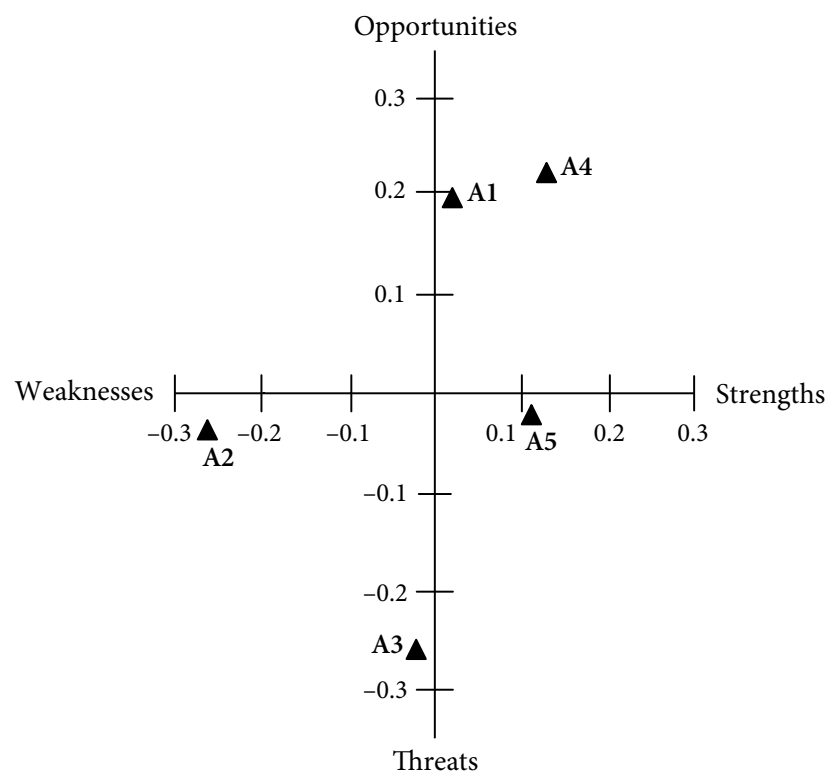

Fig. 4. The matrix of the $2^{\text {nd }}$-tier city in China under SWOT analysis

\subsection{Validation of the model}

The ANP is an approach that uses network structures to represent a multi-criteria decision-making problem and then determined the priority values for the factors from pairwise comparison matrices formed by the judgment of experts. The results will change depending on expert judgments or on the given conditions. Therefore, it is impossible for two sets of results to be the same. Although this limitation is embedded in the nature of decision-making problems, in the present study, Ihave striven to strengthen the validity of the proposed model in several ways.

Firstly, the judgments of the members of the FGD on pair-wise comparisons are combined using a geometric mean. In general, when combined judgments are used in a matrix, often the answer is closer to the actual relative values than most of the individuals' answers are (Whitaker 2007). Therefore, I adopted this method, involving geometric means, to defend the validity of our proposed model. Secondly, I analyzed the same proposed model with FAHP by assuming that the SWOT factors are independent of one another. In addition, I applied the ANP to the same model. Although similar pairwise comparison matrices are implemented under different methodologies, the results are different (Fig. 5). Such a difference is understandable because ANP accounts for all kinds of dependencies among factors in complex decision-making problems, whereas AHP does not. Thus, the ANP method is better than the AHP method for reflecting real-world problems. The proposed model not only possesses the flexibility necessary for resolving real-world dilemmas, but is also a more 
suitable and effective decision-making tool in real-world applications. Lastly, the consistency ratio (CR) of the pairwise comparison is another way to verify the validity of the mode. The CR is obtained by forming the ratio of the consistency index (CI) and the random index (RI). Saaty (1980) defined the CI and CR as follows:

$$
C I=\frac{\lambda_{\max }-n}{n-1}, \quad C R=\frac{C I}{R I} .
$$

Here, the $\lambda_{\max }$ is the maximum eigenvalue and $n$ is the size of matrix.

For each size of matrix n, random matrices are generated and their mean CI value, or RI, is computed. As suggested by Saaty (1994), the upper threshold CR values are 0.05 for a $3^{\star} 3$ matrix, 0.08 for a $4^{\star} 4$ matrix, and 0.10 for larger matrices (Lee et al. 2008). In this study, I used CR to measure the number of errors that occurred when providing the judgments. The results show that the CR of the given pairwise comparisons is below 0.1 . In other words, the errors are fairly small, and thus, I may be confident that the final reliabilityof the pairwise comparison matrices is acceptable.

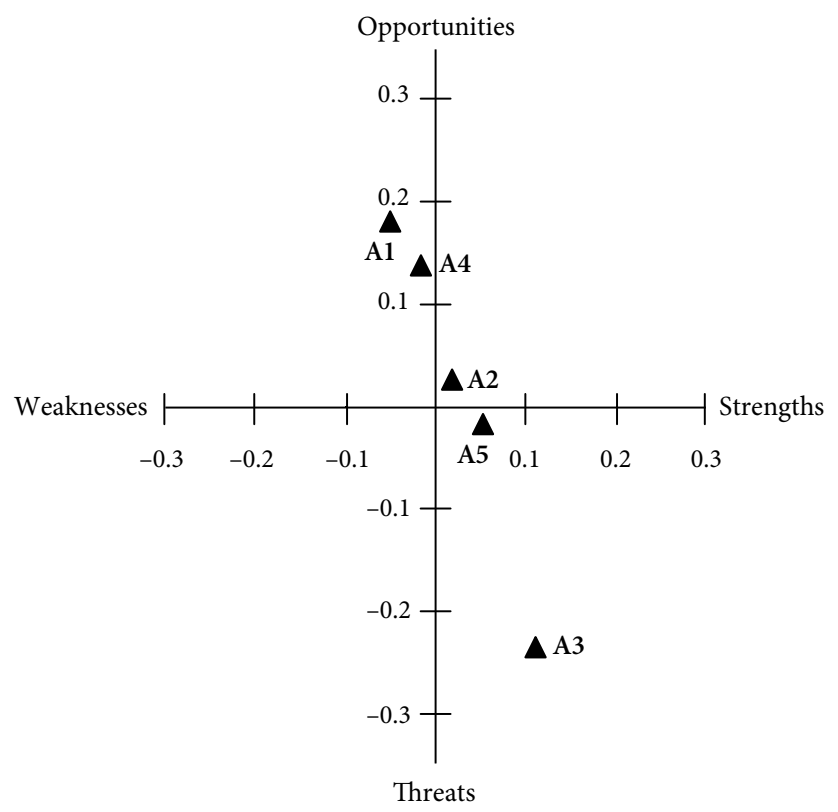

Fig. 5. The matrix of the $2^{\text {nd }}$-tier city in China based on FAHP approach

\section{Discussion}

This study makes an effort not only to select the most suitable second-tier city location for multinational pharmaceutical enterprises, but also to help the enterprises choose a strategy for development. The obtained results reveal that Chongqing and Suzhou cities are in the 
first quadrant. Enterprises in the first quadrant possess competition strength and market opportunities. A multinational pharmaceutical enterprise could adopt a niche-focus strategy into a market by focusing on specific ailments to which people in Chinese communities are vulnerable (e.g. hepatitis B, liver cancer, oral cancer, diabetes mellitus, asthma, and nasopharyngeal cancer) to increase their competing strength. Chengdu and Wuhan are in the third quadrant, where enterprises are of low competitive strength and are facing threats. A multinational pharmaceutical enterprise could enter into a market using expansionistic strategy, by means of strategic alliances with external partners, with the goal of focusing on expanding their role in the generic-drug market to lower costs, to access the local market faster, and to avoid a highly intensive competition. Xian is in the fourth quadrant, where enterprises have competition strength but are facing greater threats than opportunities, and the most urgent issue is to improve threat to intensify competitive strength. Marketing/sales services strategy could be adopted by a multinational pharmaceutical enterprise. A multinational pharmaceutical enterprise should focus on promotional activities, such as marketing research, distributing, selling, delivering, advertising, and consulting products on behalf of a licensed organization to reduce threats. A SWOT analysis is a framework for identifying the strengths, weaknesses, opportunities, and threats that underlie the development of rigorous strategy formulation. Although some researchers have proposed a SWOT analysis with ANP which enables measuring inner dependence and feedback among various factors, the drawbacks associated with ANP include crisp decision making, unbalance judgement scale, and imprecise and subjective judgement (Babaesmailli et al. 2012; Vinodh et al. 2011). To overcome the above mentioned shortcomings of the SWOT-ANP analysis, this study proposes to enhance it with fuzzylogic and the GSM technique.This research has combined the SWOT-FANP concept with GSM to develop a competitive location model. Drawing on the literature review and expert interviews from the biotech pharmaceutical field, this study has focused on five competitive locations. The decision-managers in biotech pharmaceutical enterprises can treat alternatives as a reference that will help guide the enterprise's entrance into related markets in China. Besides, I constructed the proposed model to help biotech pharmaceutical companies select competitive locations via graphs appropriate for the enterprises' own requirements. Although the decision criteria involved in any particular implementation may vary depending on the biotech pharmaceutical enterprise involved, this is one of the strengths of ANP, which can serve to construct various structures accounting for interdependences among the factors. Decision-makers can rather easily use this model structure by modifying criteria or dependence within/between criteria designed for each application, depending on the importance thatdecision-makers assigns to the application. The model proposed in the study can maintain its utility in the face of different industries. Moreover, the SWOT-FANP hybrid method featuring GSM increases and improves the information basis of strategic planning processes. It can be used as an effective framework for learning strategic decision support in numerous situations and as a communication and education tool in decision-making processes where multiple decision makers are involved. 


\section{Conclusions}

In this paper, SWOT-FANP, together with the GSM method is proposed to deal with the multiple criteria decision making (MCDC) problem of location selection for second-tier cities in China. This hybrid method can not only combine both qualitative and quantitative information and utilize fuzzy logic to eliminate vagueness, subjectivity, and imprecision but also clearly represents the competitive position of second-tier cities on the quadrant coordinate to help enterprises choose a strategy for development. To execute the study, the MNE was empirically chosen as an illustrative example. The model suggested herein consists of 1 goal, 4 assessment groups, 12 criteria, and 5 alternatives. The results reveal that Suzhou and Chongqing cities are in the best position in the competition as a result of having external opportunities for development and internal competing strength. Moreover, a MNE could adopt a niche-focus strategy into a market by focusing on specific ailments to which people in Chinese communities are vulnerable to strengthen their competing strength. This study demonstrates and validates that such an enhanced methodology is viable and highly capable of providing enriched insights regarding strategic decision-making management in complex real-world situations. To expand and refine the model, future studies may incorporate other important criteria belonging to the $\mathrm{S}, \mathrm{W}, \mathrm{O}$, and $\mathrm{T}$ groups, and may consider the possible dependencies among them. In addition, future researchers can use this model to research location selection as it applies to 3rd-tier cities' fitness for foreign investment.

\section{References}

Babaesmailli, M.; Arbabshirani, B.; Golmah, V. 2012. Integrating analytical network process and fuzzy logic to prioritize the strategies - a case study for tile manufacturing firm, Expert Systems with Applications 39(1): 925-935. http://dx.doi.org/10.1016/j.eswa.2011.07.090

Cao Y.; Liu, B.; Bai, J. 2008. Ridge regression analysison the influential factors of FDI in Jiangsu province, Canadian Social Science 4(4): 59-67.

Chang, H. H.; Huang, W. C. 2006. Application of a quantification SWOT analytical method, Mathematical and Computer Modeling 43: 158-169. http://dx.doi.org/10.1016/j.mcm.2005.08.016

Chang, D. Y. 1992. Extent analysis and synthetic decision optimization techniques and applications. Singapore: World Scientific.

Chang, D. Y. 1996. Applications of the extent analysis method on fuzzy AHP, European Journal of Operational Research 95: 649-655. http://dx.doi.org/10.1016/0377-2217(95)00300-2

Chen, S. J.; Huang, C. L.; Huang, F. P. 1992. Fuzzy multiple attribute decision making methods and applications. Berlin: Springer. http://dx.doi.org/10.1007/978-3-642-46768-4

Cheng, L.; Kwan, Y. 2000. What are the determinants of the location of foreign direct investment? The Chinese experience, Journal of International Economics 51: 379-400. http://dx.doi.org/10.1016/S0022-1996(99)00032-X

Chen, S.; Stough, R. R. 2006. Location decisions of Japanese newmanufacturing plants in China: a discretechoice analysis, The Annals of Regional Science 40: 369-387. http://dx.doi.org/10.1007/s00168-005-0052-4

Chou, C. C.; Cu, C. W.; Liang, G. S. 2001.Competitiveness analysis of major ports in Eastern Asia, Journal of the Eastern Asia Society for Transportation Studies 5: 682-697.

Coase, R. H. 1937. The nature of the firm, Economica 1: 386-405. http://dx.doi.org/10.1111/j.1468-0335.1937.tb00002.x 
Coughlin, C. C.; Segev, E. 2000. Foreign direct investment in China: a spatial econometric study, World Economy 23(1): 1-23. http://dx.doi.org/10.1111/1467-9701.t01-1-00260

Deng, J. 2000. Grey system theory and application. Taipei: Geo-Li Publishing Co.

Dunning, J. H. 2001. The Eclectic (OLI) paradigm of international production: past, present and future, International Journal of Economics and Business 8(2): 173-190. http://dx.doi.org/10.1080/13571510110051441

Dunning, J. H. 2003. Some antecedents of internalization theory, Journal of International Business Studies 34(1): 108-115. http://dx.doi.org/10.1057/palgrave.jibs.8400010

Dunning, J. H.; Lundan, S. 2008. Institutions and the OLI paradigm of the multinational enterprise, Asia Pacific Journal of Management 25: 573-593. http://dx.doi.org/10.1007/s10490-007-9074-z

Fetscherin, M.; Voss, H.; Gugler, P. 2010. 30 Years of foreign direct investment to China: an interdisciplinary literature review, International Business Review 19(3): 235-246. http://dx.doi.org/10.1016/j.ibusrev.2009.12.002

Foroughi, A.; Rasoulian, M.; Esfahani, M. J. 2012. Prioritize strategies of university by using SWOT analysis and ANP method, American Journal of Scientific Research 46: 83-91.

Giachetti, R. E.; Young, R. E. 1997. A parametric representation of fuzzy numbers and their arithmetic operators, Fuzzy Sets and Systems 91(2): 185-202. http://dx.doi.org/10.1016/S0165-0114(97)00140-1

Hill, T.; Westbrook, R. 1997. SWOT analysis: its time for a product recall, Long Range Planning 30: 46-52. http://dx.doi.org/10.1016/S0024-6301(96)00095-7

Kajanus, M.; Kangas, J.; Kurttila, M. 2004. The use of value focused thinking and the A' WOT hybrid method in tourism management, Tourism Management 2: 499-506. http://dx.doi.org/10.1016/S0261-5177(03)00120-1

Kojima, K. 1982. Macroeconomic versus international business approach to foreign direct investment, Hitotsubashi Journal of Economics 23: 630-640.

Kojima, K.; Ozawa, T. 1984. Micro and macro economic models of foreign direct investment: towards a synthesis, Hitotsubashi, Journal of Economics 43(2): 279-293.

Kuo, C. C.; Huang, J. T. 2003. A regional analysis on thedeterminants of the foreign direct investment toward Mainland China, The Western Economic Association International Pacific Rim Conference, 9-12 January 2003, Taipei, Taiwan.

Lee, A. H. I.; Chen, B. W. C.; Chang, C. J. 2008. A fuzzy AHP and BSC approach for evaluating performance of IT department in the manufacturing industry in Taiwan, Expert Systems with Applications 34: 96-107. http://dx.doi.org/10.1016/j.eswa.2006.08.022

Lee, K. L.; Lin, S. C. 2008. A fuzzy quantified SWOT procedure for environmental evaluation of an international distribution center, Information Sciences 178: 531-549.

http://dx.doi.org/10.1016/j.ins.2007.09.002

Lee, Y. H. 2012a. A fuzzy analytic network process approach to determining prospective competitive strategy in China: a case study for multinational biotech pharmaceutical enterprises, Journal of Business Economics and Management 13(1): 5-28.

http://dx.doi.org/10.3846/16111699.2011.620165

Lee, Y. H. 2012b. A fuzzy analytic network process approach to determining prospective locations in China for second-tier cities (Revised, Location selection by FANP approach), Archives Des Sciences 65(7): 282-297.

Liu, S. S.; Cheng, M. 2000. Toward a framework for entering China's pharmaceutical market, Marketing Intelligence \& Planning 18(5): 227-235. http://dx.doi.org/10.1108/02634500010343928

Liou, J. J. H.; Tzeng, G. H.; Tsai, C. T.; Hsu, C. C. 2011. A hybrid ANP mode in fuzzy environments for strategic alliance partner selection in the airline industry, Applied Soft Computing 11: 3515-3524. http://dx.doi.org/10.1016/j.asoc.2011.01.024 
Luo, Y. 2000. How to enter China: choices and lessons. Ann Arbor, MI: The University of Michigan press.

Mikhailov, L.; Singh, M. G. 1999. Comparison analysis of methods for deriving priorities in the AHP, in Proc. of the IEEE conference systems, Man, Cybernetics, 12-15 October 1999, Tokyo, Japan, 1037-1042.

Mohammad, M. F.; Abdolreza,Y. C.; Siamak, H. Y. 2011. A new methodology for prioritizing mining strategies, International Journal of Innovation, Management and Technology 2(4): 342-347.

Na, L.; Lightfoot, W. S. 2006. Determinants of foreign direct investment at the regional level in China, Journal of Technology Management in China 1(3): 262-278. http://dx.doi.org/10.1108/17468770610704930

Penrose, E. T. 1959. The theory of the growth of the firm. Oxford: Basil Blackwell.

Saaty, T. L. 1980. The analytic hierarchy process. New York, NY: McGraw-Hill.

Saaty, T. L. 1994. How to make a decision: the analytic hierarchy process, Interfaces 24(6): 19-43. http://dx.doi.org/10.1287/inte.24.6.19

Saaty, T. L. 2005. Theory and applications of the analytic network process: decision making with benefits, opportunities, costs, and risks. Pittsburgh, PA: RWS Publications.

Saaty, T. L. 2006. Rank from comparisons and from ratings in the Analytic Hierarchy/Network Processes, European Journal of Operational Research 168: 557-570. http://dx.doi.org/10.1016/j.ejor.2004.04.032

Sevkli, M.; Oztekin, A.; Uysal, O.; Torlak, G.; Turkyilmaz, A.; Delen, D. 2012. Development of a fuzzy ANP based SWOT analysis for the airline industry in Turkey, Expert Systems with Applications 39: 14-24. http://dx.doi.org/10.1016/j.eswa.2011.06.047

Sipahi, S.; Timor, M. 2010.The analytic hierarchy processand analytic network process: an overview of applications, Management Decision 48(5): 775-808. http://dx.doi.org/10.1108/00251741011043920

Stenfors, S.; Tanner, L. 2007. High level decision support in companies: where is the support for creativity and innovation?, in S. Stenfors. Strategy tools and strategy toys: management tools in strategy work. HSE Print.

Sun, Q.; Tong, W.; Yu, Q. 2002. Determinants of foreigndirect investment across China, Journal of International Money and Finance 21: 79-113. http://dx.doi.org/10.1016/S0261-5606(01)00032-8

Vinodh, S.; Ramiya, R. A.; Gautham, S. G. 2011. Application of fuzzy analytic network process for supplier selection in a manufacturing organization, Expert System with Applications 38(1): 272-2803. http://dx.doi.org/10.1016/j.eswa.2010.06.057

Wei, Y.; Liu, B.; Liu, X. 2005. Entry modes of foreign direct investment in China: a multinomial logit approach, Journal of Business Research 58: 1495-1505. http://dx.doi.org/10.1016/j.jbusres.2004.10.002

Whitaker, R. 2007. Validation examples of the analysis hierarchy process and analytic network process, Mathematical and Computer Modelling 46: 840-859. http://dx.doi.org/10.1016/j.mcm.2007.03.018

Xiao, W. G.; Zhao, Y. 2009. A study on the location determinants of the US FDI in China, Management Science and Engineering 3(2): 1-10.

Yu, J. R.; Cheng, S. J. 2007. An integrated approach for deriving priorities in analytic network process, European Journal of Operational Research 180: 1427-1432. http://dx.doi.org/10.1016/j.ejor.2006.06.005

Yüksel, İ.; Dağdeviren, M. 2010. Using the fuzzy analytic network process (ANP) for balanced scorecard (BSC): a case study for a manufacturing firm, Expert Systems with Application 37: 1270-1278. http://dx.doi.org/10.1016/j.eswa.2009.06.002

Zadeh, L. A. 1965. Fuzzy sets, Information and Control 8: 338-353. http://dx.doi.org/10.1016/S0019-9958(65)90241-X

Zhang, K. H. 2001. What attracts foreign multinational corporations to China?, Contemporary Economic Policy 19(3): 336-346. http://dx.doi.org/10.1093/cep/19.3.336

Zhou, D.; Li, S.; Tse, D. K. 2002. The impact of FDI on the productivity of domestic firms: the case of China, International Business Review 11(4): 465-485. http://dx.doi.org/10.1016/S0969-5931(02)00020-3 


\section{APPENDIX A}

The determinants of FDI in China

\begin{tabular}{|c|c|}
\hline Criteria & Author \\
\hline Transportation costs & Dunning (2003); Luo (2000) \\
\hline Wage rate & $\begin{array}{l}\text { Cao et al. (2008); Cheng, Kwan (2000); Chen, Stough (2006); } \\
\text { Coughlin, Segev (2000); Lee (2012b); Luo (2000); Kuo, Huang } \\
\text { (2003); Kojima (1982); Kojima, Ozawa (1984); Sun et al. (2002) }\end{array}$ \\
\hline $\begin{array}{l}\text { Availability, suitability, and cost } \\
\text { of land }\end{array}$ & Luo (2000); Xiao, Zhao (2009) \\
\hline Construction costs & Luo $(2000)$ \\
\hline $\begin{array}{l}\text { Cost of raw materials and } \\
\text { resources }\end{array}$ & Lee (2012b); Luo (2000) \\
\hline Financing costs & Luo (2000) \\
\hline Information costs & Luo (2000); Wei et al. (2005) \\
\hline Statutory and effective tax rates & Lee (2012b); Luo (2000) \\
\hline Tax holidays & Luo $(2000)$ \\
\hline Profit repatriation restrictions & Luo $(2000)$ \\
\hline $\begin{array}{l}\text { Market size, potential, and } \\
\text { growth }\end{array}$ & $\begin{array}{l}\text { Cao et al. (2008); Chen, Stough (2006); Lee (2012b); Luo (2000); } \\
\text { Sun et al. (2002); Xiao, Zhao (2009); Zhang (2001) }\end{array}$ \\
\hline Presence of customers & Lee (2012b); Luo (2000) \\
\hline Industrial linkages & Lee (2012b); Luo (2000) \\
\hline Local competition & Lee (2012a, 2012b); Luo (2000) \\
\hline $\begin{array}{l}\text { Market opportunities and } \\
\text { threats }\end{array}$ & Lee (2012b); Luo (2000) \\
\hline Consumer behavior & Lee (2012b); Luo (2000); \\
\hline Per capita GNP & Lee (2012a, 2012b); Luo (2000); Wei et al. (2005) \\
\hline Inflation rate & Lee (2012b); Luo (2000) \\
\hline Unemployment & Luo $(2000)$ \\
\hline Foreign exchange rate & Luo (2000) \\
\hline Tariff and non-tariff barriers & Luo $(2000)$ \\
\hline Unionization & Luo (2000) \\
\hline $\begin{array}{l}\text { Availability of special economic } \\
\text { zones }\end{array}$ & $\begin{array}{l}\text { Cao et al. (2008); Lee (2012b); Luo (2000); Kuo, Huang (2003); } \\
\text { Sun et al. (2002) }\end{array}$ \\
\hline Political instability & Luo (2000) \\
\hline Cultural barriers & Luo (2000) \\
\hline Industrial policies & $\begin{array}{l}\text { Chen, Stough (2006); Lee (2012b); Luo (2000); } \\
\text { Zhou et al. (2002); Zhang (2001) }\end{array}$ \\
\hline FDI policies & Dunning (2003); Luo (2000); Kuo, Huang (2003) \\
\hline $\begin{array}{l}\text { Government efficiency and } \\
\text { corruption }\end{array}$ & Lee (2012b); Luo (2000) \\
\hline Attitude to foreign business & Lee (2012b); Luo (2000) \\
\hline Community characteristics & Luo (2000) \\
\hline Pollution controls & Luo $(2000)$ \\
\hline
\end{tabular}


Continued Appendix A

\begin{tabular}{|c|c|}
\hline Criteria & Author \\
\hline Investment infrastructure & $\begin{array}{l}\text { Cao et al. (2008); Chen, Stough (2006); Luo (2000); } \\
\text { Sun et al. (2002); Xiao, Zhao (2009); Zhang (2001) }\end{array}$ \\
\hline Labor productivity & $\begin{array}{l}\text { Cao et al. (2008); Chen, Stough (2006); Luo (2000); } \\
\text { Na, Lightfoot (2006) }\end{array}$ \\
\hline $\begin{array}{l}\text { Skilled human resource } \\
\text { availability }\end{array}$ & $\begin{array}{l}\text { Cao et al. (2008); Chen, Stough (2006); Cheng, Kwan (2000); } \\
\text { Lee (2012a); Lee (2012b); Luo (2000); Na, Lightfoot (2006) }\end{array}$ \\
\hline International concerns & Luo (2000) \\
\hline Synergy logistics & Lee (2012b); Luo (2000) \\
\hline Input logistics & Lee (2012a, 2012b); Luo (2000) \\
\hline Market logistics & Lee (2012a, 2012b); Liu, Cheng (2000); Luo (2000) \\
\hline Investment incentives & $\begin{array}{l}\text { Chen, Stough (2006); Cheng, Kwan (2000a); Lee (2012b); } \\
\text { Luo (2000); Zhang (2001) }\end{array}$ \\
\hline Performance requirements & Luo (2000) \\
\hline Local business practices & Lee (2012b); Luo (2000) \\
\hline Agglomeration effects & $\begin{array}{l}\text { Cao et al. (2008); Chen, Stough (2006); Kuo, Huang (2003); } \\
\text { Sun et al. (2002); Wei et al. (2005); Xiao, Zhao (2009); } \\
\text { Zhou et al. (2002) }\end{array}$ \\
\hline GDP & Wei et al. (2005); Zhou et al. (2002) \\
\hline Strong brand & Lee (2012a); Liu, Cheng (2000) \\
\hline Support of funding & Lee $(2012 a)$ \\
\hline $\begin{array}{l}\text { Capability in dealing with } \\
\text { governmental rules and } \\
\text { regulations }\end{array}$ & Lee (2012a); Liu, Cheng (2000) \\
\hline $\begin{array}{l}\text { Building diverse distribution } \\
\text { channels }\end{array}$ & Lee (2012a); Liu, Cheng (2000) \\
\hline $\begin{array}{l}\text { The reform of healthcare and } \\
\text { medical insurance systems }\end{array}$ & Liu, Cheng (2000) \\
\hline
\end{tabular}

\section{APPENDIX B}

The definition of assessment criteria

\begin{tabular}{ll}
\hline Advanced R\&D capability $\left(\mathrm{S}_{1}\right)$ & $\begin{array}{l}\text { A multinational pharmaceutical enterprise's possession of } \\
\text { skilled and talented workers who can effectively study and create } \\
\text { novel innovative products. }\end{array}$ \\
\hline Strong brand $\left(\mathrm{S}_{2}\right)$ & $\begin{array}{l}\text { A multinational pharmaceutical enterprise possesses an } \\
\text { invaluable trademark reputation that makes specific promises } \\
\text { of value embedded in customers' awareness. }\end{array}$ \\
\hline Support of funding $\left(\mathrm{S}_{3}\right)$ & $\begin{array}{l}\text { A multinational pharmaceutical enterprise can obtain sufficient } \\
\text { long-term financing from diverse channels, including initial } \\
\text { public offerings, venture capital, or cash flow from product sales. }\end{array}$ \\
\hline Input logistics $\left(\mathrm{T}_{1}\right)$ & $\begin{array}{l}\text { Typical input logistics include proximity to suppliers and } \\
\text { sources of raw materials and inputs. }\end{array}$ \\
\hline
\end{tabular}


Continued Appendix B

\begin{tabular}{|c|c|}
\hline $\begin{array}{l}\text { Building diverse distribution } \\
\text { channels in rural areas } \\
\text { in China }\left(\mathrm{T}_{2}\right)\end{array}$ & $\begin{array}{l}\text { A multinational pharmaceutical enterprise needs to strive to } \\
\text { access and build diverse distribution channels in rural areas in } \\
\text { China such as hospitals, clinics, pharmacies, and e-commerce } \\
\text { establishments. }\end{array}$ \\
\hline $\begin{array}{l}\text { The development and capability in } \\
\text { traditional Chinese medicines }\left(\mathrm{T}_{3}\right)\end{array}$ & $\begin{array}{l}\text { A multinational pharmaceutical enterprise needs to strengthen } \\
\text { the development and capability in traditional Chinese } \\
\text { medicines. }\end{array}$ \\
\hline Population numbers (Size) $\left(\mathrm{O}_{1}\right)$ & The total number of people inhabiting a specific area in China. \\
\hline Per capita GNP $\left(\mathrm{O}_{2}\right)$ & Per capita gross national product. \\
\hline $\begin{array}{l}\text { The reform of healthcare and } \\
\text { medical insurance systems }\left(\mathrm{O}_{3}\right)\end{array}$ & $\begin{array}{l}\text { China's establishment of a medical and healthcare system with } \\
\text { the goal that all Chinese have basic healthcare combined with } \\
\text { (1) a commitment of pharmaceutical-bound governmental } \\
\text { investment and ( } 2 \text { ) a demand for improved medicine and } \\
\text { healthcare in both urban and rural regions. }\end{array}$ \\
\hline $\begin{array}{l}\text { Government regulation of drug } \\
\text { launches }\left(\mathrm{T}_{1}\right)\end{array}$ & $\begin{array}{l}\text { China's highly complicated oversight of the introduction of } \\
\text { pharmaceuticals. }\end{array}$ \\
\hline Highly intensive competition $\left(\mathrm{T}_{2}\right)$ & $\begin{array}{l}\text { Pharmaceutical revenue growth in China alone is projected } \\
\text { to exceed } 25 \% \text { so that both foreign and domestic companies } \\
\text { compete in this market. }\end{array}$ \\
\hline Government corruption $\left(\mathrm{T}_{3}\right)$ & $\begin{array}{l}\text { Political corruption is the use of legislated powers by } \\
\text { government officials for illegitimate private gain. }\end{array}$ \\
\hline Niche-focus strategy (SO) & $\begin{array}{l}\text { A multinational pharmaceutical enterprise's entrance into } \\
\text { a market by focusing on specific ailments to which people } \\
\text { in Chinese communities are vulnerable (e.g., hepatitis B, } \\
\text { liver cancer, oral cancer, diabetes mellitus, asthma, and } \\
\text { nasopharyngeal cancer). }\end{array}$ \\
\hline $\begin{array}{l}\text { Marketing/ sales services strategy } \\
\text { (ST) }\end{array}$ & $\begin{array}{l}\text { A multinational pharmaceutical enterprise focuses on } \\
\text { promotional activities such as marketing research, distributing, } \\
\text { selling, delivering, advertising, and consulting products on } \\
\text { behalf of a licensed organization. }\end{array}$ \\
\hline Collaborative Strategy (WO) & $\begin{array}{l}\text { A multinational pharmaceutical enterprise's entrance into a } \\
\text { market by means of strategic alliances with external partners, } \\
\text { with the goal of focusing on accessing to local distribution } \\
\text { channels and collaborating on development and capability in } \\
\text { traditional Chinese medicines. }\end{array}$ \\
\hline $\begin{array}{l}\text { Expansionistic strategy } \\
\text { (WT) }\end{array}$ & $\begin{array}{l}\text { A multinational pharmaceutical enterprise's entrance into a } \\
\text { market by means of strategic alliances with external partners, } \\
\text { with the goal of focusing on expanding their role in the generic- } \\
\text { drug market to lower cost and access local market faster. }\end{array}$ \\
\hline
\end{tabular}

Yun-Huei LEE. An Associate Professor of Business Administration at Tamkang University in Taiwan. She received her PhD in Business Management from the National Dong Hwa University in 2008. Her research interests include empirical exploration of strategic issues, more specifically focusing on international market entry strategy and new product development of technology management. 